\title{
Keteng-Keteng Development of Three Bamboo Sections
}

\author{
Adina S. Sembiring ${ }^{1}$, Uyuni Widiastuti ${ }^{2}$, Brepin Tarigan ${ }^{3}$, Lamhot B Sihombing ${ }^{4}$, \\ Hendy Obed Sembiring, ${ }^{5}$ Ewin Johan Sembiring ${ }_{-}^{6}$ \\ 1,2,3,4,5 Faculty of Languages and Arts, Universitas Negeri Medan, Indonesia \\ 'Sekolah Tinggi Teologia Sumatera Utara, Indonesia \\ Email: adinamatheny@yahoo.com
}

\begin{abstract}
:
Traditional music is music that has the characteristics of a tribe or layer of society. One of the traditional Karo music is Keteng-keteng which is played by beating with two sticks. The ketengketeng is made of buluh belin (large bamboo), the tip and base have bamboo skin. So far, ketengketeng is made from one segment of bamboo, therefore the aim of this research is to develop ketengketeng from one bamboo segment to three bamboo sections (telu ngawan) using electricity. These kettles will later use an electronic equalizer, so that the sound of the kettles produced is really an equalizer standard, which can be adjusted according to the color of the sound on the middle bass and treble. The keteng-keteng being developed is a combination of the three-segmented ketengs, the daluna-ketengs and the multi-purpose kettles, which are combined into three sections of bamboo. This is the first time this merger has been done by researchers. From this combination, two gung characters are found. which is different because Beruna uses vibrating aids while Daluna does not use vibrating aids.
\end{abstract}

\section{Keywords:}

development; keteng-keteng; three segments of bamboo

\section{Introduction}

Music is inseparable from culture and makes a positive contribution to human life. This is in line with Astono's (2004) opinion that music is part of culture in the form of a series of melodies and rhythms, and is a manifestation of a sense of human expression. In fact, music has a very important function or role so that no human being can escape from the existence of music.

Broadly speaking, the art of music consists of traditional music, modern music and contemporary music. Traditional music is music that is played and passed down from generation to generation and is always used in traditional events of each tribe such as death events, weddings, entering new homes, treating the sick and so on. Modern music is music that has been acculturated with modern technology and culture, both musical instruments and the way the music is presented. Contemporary music is music that develops which has a color or type of sound, a tempo and rhythm that varies from sound sources that come from varied sounds and not only from instrumental music.

So far, the existing keteng-keteng are only made of one piece of bamboo, so the sound produced is not optimal. Therefore, researchers will create keteng-keteng which uses three sections of bamboo, called keteng-keteng three sections of bamboo. This keteng-keteng will later use an electronic equalizer, so that it will become an electric acoustic musical instrument. The sound produced by the three sections of bamboo keteng-keteng will be a standard equalizer, which can be adjusted according to the sound color of the middle bass and treble. This change in keteng-keteng is very important in traditional karo music performances because it can minimize the keteng-keteng players which usually can be up to five players, but with the three- 


\section{Britain International of Humanities and Social Sciences (BIoHS) Journal \\ ISSN: 2685-3868(Online), 2685-1989(Print) \\ Vol. 2, No. 3, October 2020, Page: 698-705}

segment bamboo keteng-keteng-keteng-keteng-three sections of bamboo only played by three players. Usually one player with one keteng-keteng, but with the new creation, the three-section bamboo taps are played by three players according to the playing technique in the original keteng-keteng. Indirectly, this will also result in different playing techniques and variations in playing taps that are different from the existing tones.

From the explanation above, the researchers are interested in developing three-segment bamboo keteng-keteng into a single study entitled Development of Three-segment Bamboo Keteng Keteng, so that the objectives of this study are: (1) Developing three-segment bamboo keteng-keteng electric; and (2) Organological structure of three-segment bamboo keteng-keteng.

Organology is the science of the structure of musical instruments based on sound sources, how to produce sounds and a system of tuning. Organology in musical terms is the science of musical instruments, which is something that is made with the aim of producing sound. According to Kriswanto (2008) organology comes from the word organ which means object, tool or item and logi means science. So in simple terms it can be interpreted that organology is the study of objects or tools. Organology has a purpose as a description of the shape and appearance, construction of a musical instrument.

Organology studies the structure of music based on the source of sound, how to produce sound, and the system of tuning. Organology has the intention of describing the shape and form of the construction of a musical instrument so that it can produce sound. Organology in musical terms is the science of musical instruments, the study of musical instruments. According to Suroso at al, (2018) organology is the science of musical instruments, which not only covers the history and description of musical instruments, but as important as 'science' from the instrument itself, among others: performance techniques, musical functions, decorative, and variations of social culture.

A musical instrument is a tool created to produce sound, this is in line with the opinion of Soewito (1996) that a musical instrument is a means for the appearance of an art. Musical instruments can be distinguished by the source of the sound and how to play it. According to the source, the grouping of musical instruments consists of:

1. Chordhophone, a musical instrument whose sound source comes from strings or strings, such as: guitar, violin, cello, harp, alto, mandolin, banyo.

2. Aerophone, a musical instrument whose sound source is from the air, which is played by blowing it, such as: recorder, picolo, flute, trumpet, trombone, tuna, clarinet, oboe, saxsophone.

3. Idiophone, a musical instrument whose sound source comes from metal bars or wood originating from the musical instrument itself, such as: kulintang, bell, angklung, maracas.

4. Membraphone, a musical instrument whose sound source is from vibrations in a thin membrane made of leather or plastic, such as drums, gamelan, calung.

5. Electrophone, a musical instrument whose sound source is assisted or caused by an electric power, such as clavinova, organ, keyboard, electric guitar, electric bass.

Music is one of the branches of art that uses sound to express the taste of the creator. Music is an art form that is heard through the sense of hearing. According to Syafiq (2003) the art of music expresses ideas through sound whose basic elements are melody, rhythm and harmony with supporting elements in the form of ideas, properties and sound colors. In its presentation it is still combined with other elements, such as language, motion or color. 
Traditional music is music that is rooted in the traditions of a particular society, which continues today to be passed down from generation to generation to the next community. According to Purba (2007) traditional music is distinctive and reflects the culture of an ethnicity or society. Traditional music is a collection of compositions, structures, idioms and instrumentation as well as styles and elements that are not taken from a musical system originating outside the culture of a given society.

Traditional music is music that has the characteristics of a tribe or layer of society and the tones played and created by traditional musical instruments. According to Sinaga (2019) In the process of art, artists tend to consider things that can determine the quality or quality of their artwork. Some important things to note are the power of the artist's ability to manage these artistic elements, both technical and non-technical issues, such as composition issues, instrument use, playing techniques, the level of difficulty and refinement of art that can boost the aesthetic value of an artwork.

The traditional season is usually used for traditional ceremonies, religious ceremonies and entertainment. Almost all regions in Indonesia have special and distinctive traditional music. The uniqueness of traditional music can be seen from the playing technique and the organology of the musical instruments. The use of traditional music in traditional ceremonies in the karo tribe includes a wedding ceremony, death ceremony, erpangir ku lau ceremony (cleaning oneself), mengket house (entering a new house), and gendang guro-guro aron (youth party). Ginting (2019) stated that, Karo Ethnic is one of many ethnics and sub-ethnic ethnic groups which is in North Sumatra. The cultural system of Karo's community is related to its kinship system. In addition, his artistic culture is also very closely related to the kinship system in his community. Some elements of karo community culture are music, literary art (folklore, pantun), dance and art (painting, chisel or carving).

Musical activity in Karo culture is known by two terms, namely ergendang and rende. Ergendang consists of two words, namely: "er" which means to do something and "gendang" which simply means music. So ergendang can be interpreted as "Playing Music". Gendang can mean a musical instrument, a ceremony, a composition title and several other meanings. All musical instruments in the realm of karo culture are grouped into two traditional karo music ensembles, namely the five sedalenan drum and the telu sedalenan drum.

Rende is generally defined as singing, while ende-ende means singing. Karo people who are good at singing are called parende-rende, who are called to sing as well as dance in the context of an event called perkolong-kolong, Tarigan (2004: 192).

Karo Traditional Music has several types of music including:

1. Drum as the meaning to show a certain type of music, such as the karo drum.

2. Gendang as the name of a musical instrument, such as the singindung drum, singanaki drum.

3. Gendang to show the type of song or a certain musical composition, such as the Simalungun Raya drum, the persekeluken drum.

4. Gendang to mean a certain ceremony, such as gendang cawir metua, gendang guro-guro aron.

Traditional karo musical instruments can be classified according to their sound source, such as: Chordhophone is on kulcapi and murbab musical instruments, Aerophone is in surdan, sarune, balobat and appendix musical instruments, Membraphone is on the singanaki drum, singindung drum, and Idiophone there on a drum musical instrument. 
Keteng-keteng which is one of the traditional musical instruments in the Karo community is played by beating it with two sticks. The keteng-keteng is made of buluh belin (large bamboo), the tip and base have bamboo skin. Two parts of the bamboo skin are removed from the line, each $1 \mathrm{~cm}$ wide. The two bamboo skins are stretched with wood / bamboo. In the middle of this keteng-keteng instrument, a hole is made and a lid is made into the stretched bamboo skin. The technique of playing the keteng-keteng is done by using the hitting technique (odak), where the hitting technique requires two bamboo sticks.

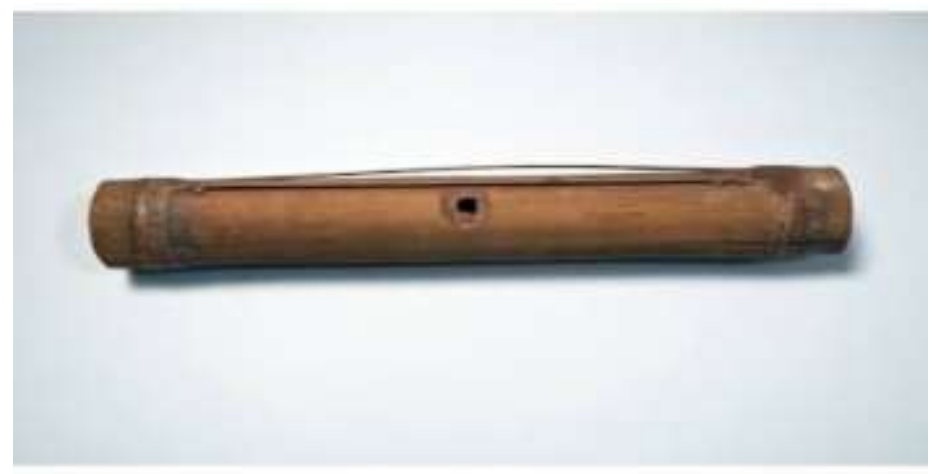

Figure 1. Keteng-keteng Musical Instruments

Keteng-keteng is about half a meter long and has strings made of bamboo strips consisting of two pieces. Keteng-Keteng length is $58 \mathrm{~cm}$, medium line is about $12 \mathrm{~cm}$. How to play this instrument is very simple like hitting a drum instrument. In terms of its function, the keteng-keteng is often played in the music of the telu sendalanen drum as a medium for the Erpangir Ku Lau ceremony by the Karo people.

\section{Research Methods}

\subsection{Research Approach}

This research approach is qualitative with the type of research assessment and exploration of the creation of works of art. The process of tracing data and information is carried out diachronic to determine in a complete and sequential manner the development of three bamboo kettles.

\subsection{Data Sources}

Sources of data in this study use primary and secondary data. Primary data is data obtained directly from informants, namely keteng-keteng makers at the Mejuah Juah Gallery Jalan Perumahan Salam Tani Blok E No. 40 Crushed Stone. Primary data is obtained through in-depth interview techniques and participant observation which aims to find data accuracy which is also followed by conducting focus group discussions in formulating and defining concepts in the development of keteng-keteng three sections of bamboo. Secondary data is data obtained from other sources, such as: books, records, journals, or from other sources in order to support research data.

\subsection{Data Collection Techniques}

Data collection techniques in this study are:

1. Observation, is done to confirm the data that has been collected by observing directly.

2. Interview, used for communication with related parties such as keteng-keteng makers in the mejuah-juah gallery.

3. Documentation, is done to support the research process, where not all things can be known. Therefore, it can be done by taking notes, transcripts, books, recordings and so on. 


\subsection{Data Analysis Techniques}

The data analysis technique is done by categorizing and analyzing primary data and secondary data through expert discussions. Next, formulate a concept and model for the development of three bamboo kettles.

\section{Result and Discussion}

Based on the concept of organology regarding the structure of music based on the source of sound, how to produce sound, and the tuning system, keteng-keteng can be categorized as an Idiophone instrument, which is a musical instrument whose sound source comes from metal or wood rods from the musical instrument itself.

The way to play keteng-keteng is very simple like hitting a drum instrument. Judging from its function, this musical instrument used to be played in the context of a sedalenan drum ensemble as a medium in the Erpangir Ku Lau ceremony (thanksgiving to DibataTuhan) by the karo community. Lately, keteng-keteng instruments are also often played in various performances for the purpose of being mere entertainment. The form and method of playing Keteng-keteng are simple, but they play a big role in traditional karo music because ketengketeng carries the characteristics of traditional Karo music.

Keteng-keteng has two types, namely keteng-keteng-dalu-dalu and keteng-keteng-beru. To distinguish keteng-keteng-dalu-dalu and keteng-keteng-beru-beru can be seen from the number of ropes. The keteng-keteng dalu-dalu has three ropes, while the keteng-beru-beru has two ropes and has a tongue or ampik-ampik.

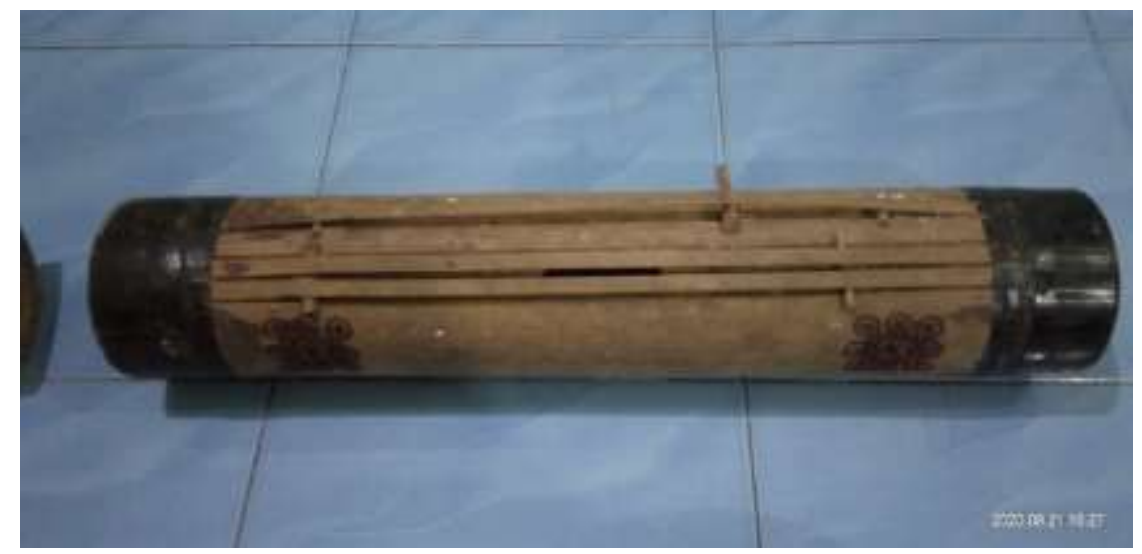

Figure 2. Keteng-keteng Dalu-dalu

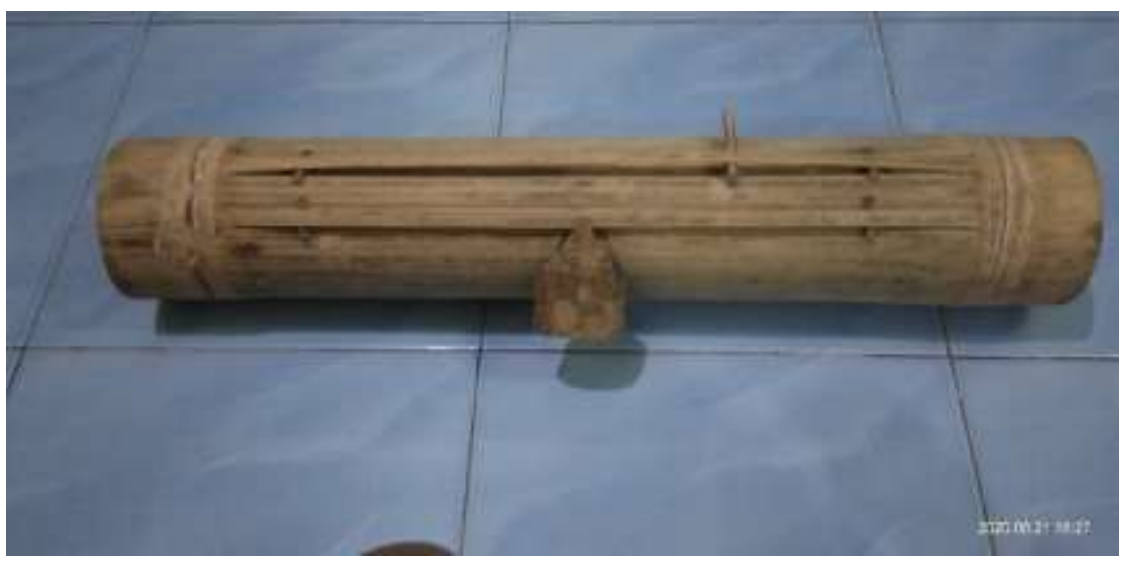

Figure 3. Keteng-keteng Beru-beru 
The function of the keteng-keteng instrument in the kulcapi drum musical ensemble is as an accompaniment in a reportoar or song. In the context of tradition, only keteng-keteng dalu-dalu can be used for traditional ceremonies, while keteng-keteng beru-beru can only be used during practice. This kulcapi drum ensemble is generally used in various rituals, namely erpangir kulau, muncang and raleng tendi.

\subsection{Development of Keteng-keteng Three Bamboo Sections}

In line with the times, keteng-keteng can be developed into three sections of bamboo so that the function of keteng-keteng in one karo music composition is not only an accompaniment to rhythmic patterns that are constant and repetitive (repetitive), but develop into varied rhythms and polyritem. So far, in an ensemble the keteng-keteng has functioned as a rhythm but can also be a rhythm that presents variations.

So far, there is no known development of keteng-keteng in its form, only the development of rhythm in the keteng-keteng game. Through this research, the researcher will develop the traditional keteng-keteng (one segment of bamboo) to become the Keteng-Keteng Tiga Ruas Bambu. Keteng-keteng developed in this study still uses bamboo as the basic material, but changes that can be seen in these kettas include the shape of the kettles that are longer than usual (about 1.5 meters) and the sound of a kettle that produces three characters, namely High, Medium and Low because it has been added to the equalizer. In terms of music players, the three sections of bamboo keteng-keteng can also be minimized, which should be a five-person keteng-keteng player, but with the development of Keteng-Keteng Tiga Ruas Bambu, it can be played with only three players. From the point of view of using keteng-keteng also seems to be minimized again, which should be playing keteng-keteng as many as five players, but with Keteng-Keteng Three Segment of Bamboo can be played one keteng-keteng only.

Before developing the keteng-keteng as one of the traditional Karo musical instruments, it is necessary to conduct an assessment of several studies related to keteng-keteng, both in terms of developing keteng-keteng playing techniques, developing keteng-keteng rhythm patterns and so on. The method used in the development of musical instruments based on the Karo tradition, in this case, is keteng-keteng, using a study approach and exploration of art creation. The information obtained by researchers in this study was obtained from an informant who is an artist and keteng-keteng maker in the village of Pancur Batu, Deli Serdang, North Sumatra.

The process of collecting data and information is carried out systematically by preparing equipment and needs while in the field. Data obtained from several sources (primary data and secondary data) were collected to become valid data in developing bamboo keteng-ketengs. Primary data was obtained from a resource person, Mr. Fauzi Ginting, who is in the village of Pancur Batu, Deli Serdang Regency, North Sumatra. Primary data were obtained through indepth interviews with sources and observations to find the accuracy of the data which was also followed by conducting group discussions in a focus group discussion in formulating and establishing the concept of developing keteng-keteng as traditional karo music. Secondary data are used only through observation to support data obtained from the main source.

The creation of a three-segment kettle is carried out by exploring the timbre in one bamboo which has three sections. The three bamboo sticks are tuned differently by means of the strings and resonance holes and the dilah or vibrating tongue. The three characters, namely high, midle, and low, will be determined by the thickness of the strings and the size of the resonant hole and the size of the dilah. 
The drum with high string character will be made very thin and the resonant hole must be small, as well as the dilah. The keteng-keteng has a middle character, the strings are a little thicker, the resonance hole is also slightly bigger. Keteng-keteng has low character, the strings must be thick, dilah and the resonance hole must also be bigger.

The creation of theree section of bamboo keteng-keteng in this study combines ketengketeng daluna and keteng-keteng beruna. Visually, these three sections of keteng-keteng are also the only keteng-keteng newly created where the two types of ketengs are in one bamboo blade. In addition, this keteng-keteng will also be implanted with a sound amplifier or equalizer whose function is besides being a loudspeaker, it also helps to strengthen or get high, midle, and low characters.

This method was used for the first time in the process of making keteng-keteng in general. Previously, there had never been a loudspeaker like an equalizer and there had never been a keteng-keteng daluna and beruna being in one bamboo blade. The development of the three-segment keteng-keteng as described above is expected to be a new alternative in the development of the karo art, especially in the realm of the performing arts without losing the essence of the original keteng-keteng.

\subsection{Describe the Organological Structure of the Keteng-Keteng Electric Telu Ngawan (Three Bamboo Segments)}

Organology is the study or description of shape and structure. Organology comes from the word organ which means object and logi (logos) which means science. Before being able to dissect the organology of keteng tigaruas, the researcher first classified the keteng-keteng based on their sound source. It is known that based on their sound source, musical instruments can be divided into:

1. Ideofon: a musical instrument whose sound source is the body of the musical instrument itself

2. Aerofon: a musical instrument whose source of sound is air

3. Membranofon: a musical instrument whose sound source is a membrane or skin

4. Kordofon: a musical instrument whose source sounds in the form of chords, ropes or strings

5. Elektrophon: a musical instrument whose source of sound comes from electricity

From the above explanation, it can be concluded that the keteng-keteng falls into the category of ideophones (musical instruments whose sound source is the body and the musical instrument itself). Due to the tuga ringing of the bamboo segment, the sound source comes from the body of the instrument itself. Here is the keteng-keteng organology in the form of an image:

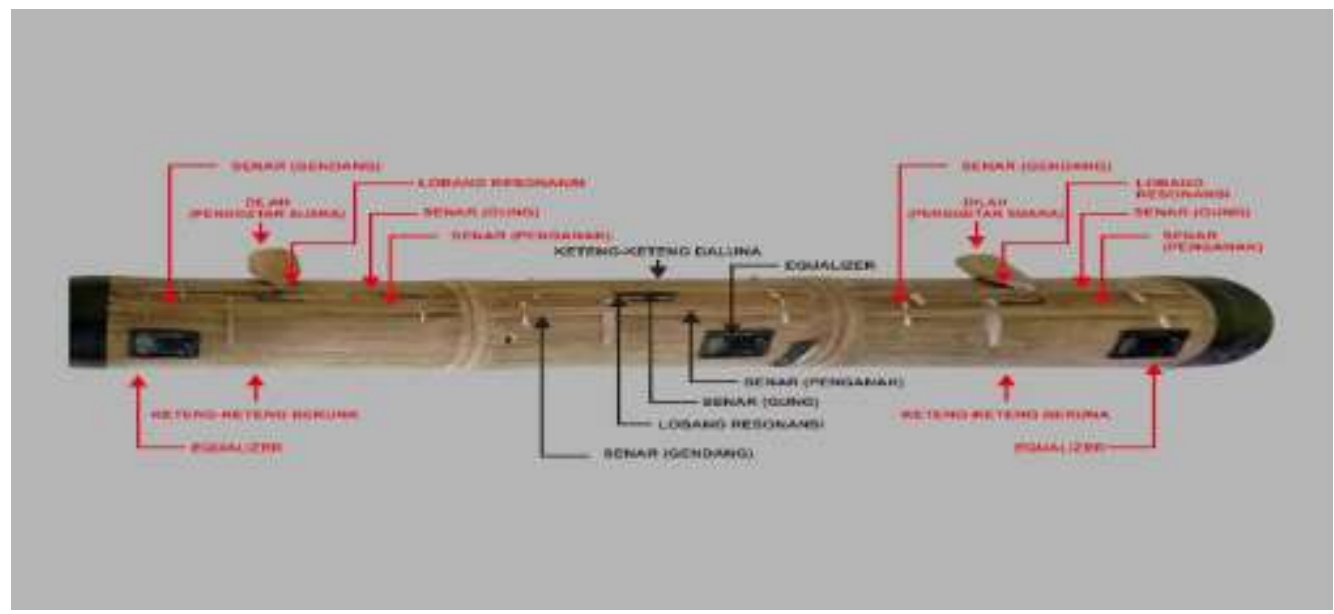

Figure 4. Keteng-keteng Tiga Ruas Bambu 
The keteng-keteng being developed is a combination of the keteng-keteng threesegment, the keteng-keteng daluna and the keteng-keteng beruna that are joined together into three sections of bamboo. This is the first time this merger has been done by researchers. From this combination, two gung characters are found which is different Beruna uses vibrating aids while Daluna does not use vibrating aids.

\section{Conclusion}

Traditional music is music that has the characteristics of a tribe or layer of society. One of the traditional Karo music is Keteng-keteng which is played by beating with two sticks. The keteng-keteng is made of buluh belin (large bamboo), the tip and base have bamboo skin. So far, keteng-keteng is made of one bamboo segment, therefore the aim of this research is to develop keteng-keteng from one bamboo segment to three bamboo segments using electricity. These keteng-keteng will later use an electronic equalizer, so that the sound of the keteng-keteng produced is really an equalizer standard, which can be adjusted according to the color of the sound on the middle bass and treble. The keteng-keteng being developed is a combination of the keteng-keteng three-segment, the keteng-keteng daluna and keteng-keteng beruna that are joined together to form three sections of bamboo. This is the first time this merger has been done by researchers. From this combination, two gung characters are found which is different because beruna uses vibrating aids while daluna does not use vibrating aids.

\section{References}

Astono, Sigit, dkk. (2004). Apresiasi Seni Tari dan Seni Musik. Yogyakarta: Yudistira.

Ediwar, dkk. (2019). Kajian Organologi Pembuatan Alat Musik Tradisi Saluang Darek Berbasis Teknologi Tradisional . Jurnal Seni Budaya PanggungVol.2 No. 2

Ginting, P. P. (2019). Music Creation Based on Folklore. Budapest International Research and Critics Institute-Journal (BIRCI-Journal), 271-278.

Matsunobu, Koji. (2013). Instrument-Making As Music-Making: An Ethnographic Study Of

"Shakuhachi" Students' Learning Experiences. International Journal of Music Education, v31 n2 p190-201.

Purba, Mauli. (2007). Musik Tradisional Masyarakat Sumatera Utara: Harapan Peluang, Dan Tantangan. Medan. Universitas Sumatera Utara

Soewito. (1996). Mengenal Alat-alat Musik Tradisional, Yogyakarta : Sinar Harapan

Syafig, Muhammad. (2003). Ensiklopedia Musik Klasik, Yogyakarta: Adicita Karya Nusa.

Tarigan, Perikuten. (2004). Pluralitas Musik Etnik.Pusat Dokumentasi dan Pengkajian Kebudayaan Batak. Universitas HKBP Nommensen.

Sagala, Mastri Dihita. (2017). Pola Irama Keteng-Keteng Dalam Pertunjukan Gendang Telu Sendalanen Masyarakat Karo, S1 thesis, Universitas Pendidikan Indonesia.

Sinaga, T. (2019). Music Composition of Accompaniment for Fusion Dance 8 Ethnics of North Sumatera. Budapest International Research and Critics Institute-Journal (BIRCIJournal), 321-327.karo

Suroso, P., at al. (2018). Performance Model of Kulcapi (Karo Musical Instrument) as a Teaching Material in Guitar Learning. Budapest International Research and Critics Institute-Journal (BIRCI-Journal), 136-143. 